\author{
Beata Stypułkowska ${ }^{1}$ \\ Wyższy Instytut Teologiczny w Częstochowie
}

\title{
Katecheza biblijna w parafii skierowana do różnych grup dorosłych
}

Jak podają statystyki za rok 2013, w niedziele na mszę świętą uczęszcza 39,1 proc. wiernych, a 16,3 proc. przyjmuje Komunię Świętą ${ }^{2}$ Jeżeli już Polacy uczestniczą we mszy świętej, to w niedostatecznym stopniu czynnie angażują się w jej przeżywanie. $Z$ badań wynika że aż 62,2 proc. uczestników liturgii nie spełnia żadnych posług liturgicznych, a w polskich parafiach brakuje grup przygotowujących niedzielną liturgię: wspomina o tym 39,5 proc. respondentów ${ }^{3}$. Te dane wskazują na potrzebę ożywienia katechezy dorosłych w parafii przygotowującej do liturgii. Taką rolę może spełniać katecheza biblijna.

Zagadnienie katechezy dorosłych było już podejmowane w różnych ujęciach. Zarys teorii podał Romuald Niparko pod koniec lat osiemdzie-

1 Beata Stypułkowska - doktor teologii, wykładowca katechetyki w Wyższym Instytucie Teologicznym w Częstochowie od roku 2000. Pracę doktorską Teoretyczne i praktyczne założenia przygotowania katechetów do poprawnej interpretacji tekstów biblijnych z uwzględnieniem form samokształcenia kierowanego, napisaną pod kierunkiem bpa dra hab. Antoniego Długosza, obroniła na Wydziale Teologicznym Papieskiej Akademii Teologicznej w Krakowie w grudniu 1998 roku. E-mail: stypulkowska.czwa@gmail.com.

2 http://episkopat.pl/kosciol/kosciol_w_polsce/statystyki/6013.1,Zestawienie_dominicantes_i_communicantes_2013.html (2016.03.30).

3 http://www.opoka.org.pl/biblioteka/T/TA/TAP/communicantes2013.html (2016.03.30). 
siątych ubiegłego wieku $u^{4}$. Natomiast Stanisław Łabendowicz w tym aspekcie prześledził dokumenty i literaturę posoborową ${ }^{5}$. Niezwykle cenny jest również artykuł Romana Murawskiego traktujący o kierunkach i formach pracy katechetycznej z dorosłymi ${ }^{6}$. Wszyscy autorzy zwracają uwagę na parafię jako środowisko i miejsce katechezy dorosłych ${ }^{7}$. Ze względu na znaczenie duszpasterstwa biblijnego wydaje się wskazane przebadanie katechezy dorosłych w parafii pod kątem katechezy biblijnej. W publikacjach podejmujących to zagadnienie ukazano katechezę biblijną dorosłych w parafii w sposób ogólny, traktując dorosłych jako zwartą grupę katechizowanych, nie różnicując dorosłych między sobą ${ }^{8}$ W niniejszym artykule zwrócono uwagę na różne grupy dorosłych, do których winna być skierowana odpowiednia katecheza, w tym również katecheza biblijna otwierająca na spotkanie z Chrystusem obecnym w słowie Bożym.

W niniejszym artykule, bazującym na dokumentach kościelnych i opracowaniach katechetycznych, zostaną przedstawione kolejno: zagadnienie duszpasterstwa katechetycznego w parafii, etapy katechezy parafialnej, grupy osób dorosłych objętych katechezą oraz treści katechezy biblijnej w parafii.

\section{Duszpasterstwo katechetyczne w parafii}

Jan Paweł II w adhortacji apostolskiej Catechesitradendae porusza problematykę parafii jako środowiska katechezy. Papież podkreśla, że wspólnota parafialna, jako zajmująca szczególne miejsce w Kościele, powinna

4 R. Niparko, Katecheza dorosłych. Zarys teorii, Poznań 1987.

5 S. Łabendowicz, Katecheza dorostych Kościoła posoborowego w świetle dokumentów i literatury katechetycznej, Radom 2007.

6 R. Murawski, Kierunki i formy pracy katechetycznej z dorosłymi w parafii, „Śląskie Studia Teologiczno-Historyczne" 13 (1980), s. 65-80.

7 R. Niparko, Katecheza dorostych..., dz. cyt., s. 46-54; S. Łabendowicz, Katecheza dorosłych Kościoła posoborowego w świetle dokumentów i literatury katechetycznej, dz. cyt., s. 338-376; R. Murawski, Kierunki i formy pracy katechetycznej z dorostymi w parafii, art. cyt., s. 65-80.

8 B. Stypułkowska, Katecheza biblijna w parafii skierowana do osób dorosłych, „Analecta Cracoviensia" 46 (2014), s. 155-170; B. Stypułkowska, Biblijna formacja katechetów, Częstochowa 2015, s. 263-278. 
pozostać krzewicielką i inspiratorką katechezy, a parafia jest w dalszym ciągu miejscem, w którym chrześcijanie, nawet niepraktykujący, są związani ścisłymi więzami ${ }^{9}$.

Papież Franciszek w adhortacji apostolskiej Evangelii gaudium o głoszeniu Ewangelii w dzisiejszym świecie mówi wprost, że parafia nie jest strukturą przestarzałą ${ }^{10}$. I z tego powodu, że ma wielką elastyczność, może przyjąć różne formy, wymagające otwarcia i misyjnej kreatywności ze strony duszpasterza i wspólnoty. Dotyczy to również katechezy. Chociaż parafia z pewnością nie jest jedyną instytucją ewangelizacyjną, to jednak jeśli zachowuje zdolność do nieustannego reformowania się i przystosowania, nadal będzie formą obecności Kościoła na danym terytorium, środowiskiem słuchania słowa, wzrostu życia chrześcijańskiego, dialogu, przepowiadania, ofiarnej miłości, adoracji i celebracji. Rzeczywiście będzie utrzymywała kontakt z rodzinami i z życiem ludu. Przez całą swoją działalność parafia pobudza i formuje swych członków, aby byli ludźmi ewangelizującymi ${ }^{11}$. Papież Franciszek jednak przyznaje, że wezwanie do rewizji i odnowy naszych parafii nie przyniosło jeszcze wystarczających owoców, aby były one bliżej ludzi i były środowiskami żywej komunii i uczestnictwa oraz ukierunkowały się całkowicie na misję ${ }^{12}$.

Benedykt XVI natomiast w adhortacji apostolskiej Verbum Domini zwraca uwagę na to, że parafia może być środowiskiem duszpasterstwa biblijnego. Takie duszpasterstwo ma być nie tyle jedną z form duszpasterstwa, ile biblijną animacją całego duszpasterstwa, które przyczyni się do lepszego poznania osoby Chrystusa w celu osobistego spotkania z Nim, objawiającym się w swoim słowie ${ }^{13}$. Zatem parafia może być właściwym miejscem katechezy biblijnej.

Dyrektorium ogólne o katechizacji wskazuje parafię jako najbardziej znaczące miejsce, w którym formuje się i żyje wspólnota chrześcijańska ${ }^{14}$.

\footnotetext{
9 Jan Paweł II, adhort. apost. Catechesi tradendae [dalej: CT], 67.

10 Franciszek, adhort. apost. Evangelii gaudium [dalej: EG], 28.

11 EG 28.

12 EG 28.

13 Benedykt XVI, adhort. apost. Verbum Domini [dalej: VD], 73.

14 Kongregacja ds. Duchowieństwa, Dyrektorium ogólne o katechizacji [dalej: DOK], Poznań 1998, 257.
} 
Jest to ponadto zwyczajne środowisko, w którym rodzi się i wzrasta wiara ${ }^{15}$. Dlatego też powinna pozostać „krzewicielką i inspiratorką katechezy”' Roman Murawski zauważa, że normy, kryteria i propozycje zamieszczone w Dyrektorium ogólnym o katechizacji dotyczą głównie katechezy parafialnej ${ }^{17}$.

\section{Etapy katechezy parafialnej}

Warto zwrócić uwagę, że w parafii są realizowane zwykle dwie formy katechezy: katecheza wtajemniczająca dorosłych, dzieci i młodzieży oraz katecheza stała ${ }^{18}$. Powinny one być ze sobą powiązane i zintegrowane. Istotnym zadaniem katechezy wtajemniczającej jest wprowadzenie w pełnię życia chrześcijańskiego ${ }^{19}$. Jest ona ściśle związana z sakramentami wtajemniczenia chrześcijańskiego ${ }^{20}$. Katecheza stała skierowana jest do chrześcijan już wprowadzonych w podstawowe elementy, które powinny ożywiać i prowadzić do dojrzałości ich wiarę w ciągu całego życia ${ }^{21}$.

Dokumenty kościelne przedstawiają jednak katechezę jako część szeroko pojętej ewangelizacji ${ }^{22}$, a ewangelizację przedstawiają jako proces ${ }^{23}$. Wymieniane są zazwyczaj trzy jej etapy ${ }^{24}$. Pierwszym etapem ewangelizacji jest działanie misyjne dla niewierzących i dla żyjących w obojętności religijnej. Drugim etapem jest działanie katechetyczno-wtajemniczające dla tych, którzy wybierają Ewangelię, i dla tych, którzy pragną uzupełnić lub odnowić wtajemniczenie chrześcijańskie. Trzecim etapem jest działanie duszpasterskie dla już dojrzałych chrześcijan we wspólnocie chrześ-

\footnotetext{
15 DOK 257.

16 CT 67; DOK 257.

17 R. Murawski, Działania katechetyczne w parafii w świetle Dyrektorium Ogólnego i Polskiego,
} w: Przesłanie dokumentów katechetycznych Kościoła w Polsce, red. S. Dziekoński, Warszawa 2003, s. 56.

18 DOK 72; R. Murawski, Działania katechetyczne w parafii, art.cyt., s. 60-61.

19 CT 18; DOK 63.

20 DOK 66.

${ }^{21}$ DOK 51 wraz z przypisem 64.

22 DOK 62.

23 DOK 48; Konferencja Episkopatu Polski, Dyrektorium katechetyczne Kościoła katolickiego w Polsce [dalej: PDK], Kraków 2001, 54.

24 DOK 49; PDK 55; Z. Marek, Jezus Chrystus w katechezie ewangelizacyjnej, w: Ewangelizować czy katechizować, red. S. Dziekoński, Warszawa 2002, s. 89. 
cijańskiej. Jan Paweł II w adhortacji Catechesi tradendae wychodzi z założenia, że ewangelizacja i katecheza nie są tożsame, ale oba działania są ze sobą związane i wzajemnie się uzupełniają ${ }^{25}$. Katechetycy zaczęli mówić o katechezie ewangelizacyjnej skierowanej do osób, które formalnie uczestniczą w katechezie Kościoła, ale jeszcze nie opowiedzieli się wyraźnie za Chrystusem ${ }^{26}$.Z taką sytuacją mamy niejednokrotnie do czynienia w szkolnym nauczaniu religii, które jest określone przez polskie dyrektorium katechetyczne jako specyficzna forma katechezy ${ }^{27}$.

Specyficznym celem katechezy jest rozwinięcie wiary początkowej, doprowadzenie do jej pełni i codzienne zasilanie życia chrześcijańskiego wiernych $^{28}$. Domaga się to pewnych etapów i rozłożenia działania katechetycznego w czasie, uwzględniając również osoby dorosłe, przy czym można mówić o katechezie ewangelizacyjnej ${ }^{29}$, katechezie wtajemniczającej, katechezie mistagogicznej ${ }^{30} \mathrm{i}$ katechezie stałej.

25 CT 18.

${ }^{26}$ W dniach 22-23 września 2009 roku odbyło się w Częstochowie sympozjum Sekcji Wykładowców Katechetyki zatytułowane Ewangelizacyjne zadania katechezy. W pozycji posympozjalnej opublikowano wszystkie wystąpienia z tego sympozjum oraz artykuły katechetyków reprezentujących ośrodki naukowe poświęcone katechezie ewangelizacyjnej: Katecheza ewangelizacyjna. Poszukiwania koncepcji, red. P. Mąkosa, Lublin 2010. Określenie „katecheza ewangelizacyjna" nie jest wprawdzie precyzyjne, ale wyraża aktualne zaangażowanie katechetyków w dzieło ewangelizacji. Przepowiadanie Ewangelii dokonuje się w trzech podstawowych typach - jako: misyjne, katechetyczne i homilijne: por. H. Sławiński, Między ciagłościa a zmiana. Teoria homilii w Stanach Zjednoczonych po II Soborze Watykańskim, Kraków 2008, s. 6, 32.

27 PDK 82.

28 CT 20.

29 Na temat katechezy ewangelizacyjnej oraz wzajemnych relacji między ewangelizacją a katechezą zob.: P. Tomasik, Ewangelizacja - katecheza - nauczanie religii w szkole. Wyjaśnienie podstawowych terminów, w: Ewangelizować czy katechizować, s. 23-51; A. Offmański, Model katechezy ewangelizacyjnej $w$ dokumentach Kościoła, w: Ewangelizować czy katechizować, s. 53-72; J. Neumann, Dlaczego katecheza ewangelizacyjna?, w: Ewangelizować czy katechizować, s. 133-143; J. Kochel, Katecheza ewangelizacyjna w nauczaniu pastoralnym Carlo Maria Kard. Martiniego, Opole 1999, s. 99-176; P. Tomasik, Katecheza w misji ewangelizacyjnej Kościoła, „Katecheta” 42 (1998) nr 6-7, s. 9-18; A. Offmański, Katecheza jako ewangelizacja. Ewangelizacyjna funkcja katechezy, „Horyzonty Wiary” 7 (1996) nr 3, s. 9-20; P. Nonis, Ewangelizacja a katecheza, w: Nowa ewangelizacja, red. L. Balter i in., Poznań 1993, s. 96-100 (Kolekcja Communio, 8); R. Murawski, Ewangelizacyjny charakter katechezy, „Ateneum Kapłańskie” 84 (1992) nr 2, s. 181-193; S. Łabendowicz, Katecheza w stużbie ewangelizacji, „Roczniki Teologiczno-Kanoniczne” 36 (1989), z. 6, s. 129-145.

30 Obrzędy chrześcijańskiego wtajemniczenia dorosłych. Dostosowane do zwyczajów diecezji polskich [dalej: OCWD], Katowice 1988 okres mistagogii, czyli pogłębionego wtajemniczenia, sytuują po otrzymaniu przez wierzącego sakramentów wtajemniczenia. Wówczas cała wspól- 
Katecheza ewangelizacyjna ma wprowadzić katechizowanego na drogę wiary, jest etapem wstępnym. Zadaniem katechezy wtajemniczającej jest wprowadzenie w pełnię życia chrześcijańskiego ${ }^{31}$. Katecheza wtajemniczająca jest ściśle związana z sakramentami wtajemniczenia chrześcijańskiego $^{32}$ : chrztem, bierzmowaniem i Eucharystiąa ${ }^{33}$. Chrzest związany jest ściśle z wyznaniem wiary, co jest również celem katechezy ${ }^{34}$. Katecheza ma być uporządkowanym i systematycznym wprowadzeniem w objawienie zachowane w tradycji Kościoła i w Piśmie Świętym ${ }^{35}$. Katecheza wtajemniczająca jest katechezą podstawową ${ }^{36}$, skoncentrowaną na Osobie Jezusa Chrystusa ${ }^{37}$. Istotnym elementem wtajemniczenia chrześcijańskiego jest zrozumienie również ścisłej więzi Biblii z liturgią ${ }^{38}$.W liturgii natomiast czytane są teksty zarówno z Nowego, jak i Starego Testamentu, co wskazuje na potrzebę wprowadzania katechizowanych już na początkowym etapie w całość orędzia biblijnego, a nie tylko w treść Ewangelii. Jedność i harmonia obu Testamentów, oparta na chrystocentryzmie, jest elementem konstytutywnym współczesnej katechezy biblijnej na wzór katechezy apostolskiej i patrystycznej ${ }^{39}$. Katecheza stała skierowana jest do chrześcijan już wprowadzonych w podstawowe elementy, które powinny ożywiać i prowadzić do dojrzałości ich wiarę w ciągu całego życia ${ }^{40}$. Katecheza stała zakłada katechezę wtajemniczającą. Skierowana jest nie tylko do każdego wierzącego, ale także do wspólnoty chrześcijańskiej, od której wymaga wierności wobec działania Ducha Świętego, ciągłego

\footnotetext{
nota razem z nowo ochrzczonymi przez rozważanie Ewangelii, uczestnictwo w Eucharystii i uczynki miłosierdzia postępuje w głębszym poznaniu misterium paschalnego i usiłuje coraz lepiej urzeczywistniać je w praktyce życia - OCWD, n. 37. Na temat katechezy mistagogicznej zob. K. Misiaszek, Mistagogia w katechezie, w: Mistagogia a duchowość, red. A. Żądło, Katowice 2004, s. 81-90.

31 CT 18; DOK 63.

32 DOK 66.

33 DOK 65.

34 DOK 66.

35 CT 22; DOK 66.

36 CT 21; DOK 67, 69.

37 DOK 67.

38 PDK 59.

39 PDK 59.

40 DOK 51 wraz z przypisem 64.
} 
karmienia się Eucharystią i stałego wychowania wiary przez słuchanie słowa ${ }^{41}$. Wśród form katechezy stałej Dyrektorium ogólne o katechizacji wymienia studium i pogłębienie Pisma Świętego czytanego nie tylko w Kościele, lecz także z Kościołem ${ }^{42}$.

\section{Grupy dorosłych w parafii podzielone ze względu na zaangażowanie $w$ wiarę}

Dokumenty kościelne ukazują parafię jako szczególne miejsce katechezy dorosłych. Dyrektorium katechetyczne Kościoła katolickiego w Polsce temat duszpasterstwa katechetycznego w parafii zaczyna właśnie od zagadnienia katechezy dorosłych, ponieważ katecheza dorosłych realizuje się prawie w całości w parafii ${ }^{43}$. Dlatego też katecheza w parafii powinna być w szczególny sposób ukierunkowana na dorosłych ${ }^{44}$, w katechezie rodzinnej obejmując również dzieci i młodzież. Katecheza dorosłych jednak powinna być podjęta przez parafię jako jej priorytet duszpaster$\mathrm{ski}^{45}$. Dlatego ważne jest również zbadanie parafii jako środowiska katechetycznego. Pytanie o koncepcję katechezy dorosłych wiąże się ściśle z pytaniem o koncepcję parafii ${ }^{46}$. Parafia, która jest rzeczywistą wspólnotą wierny $\mathrm{ch}^{47}$, wypełnia zadania jednoczenia ich $\mathrm{w}$ wierze, kulcie i miłości braterskiej ${ }^{48} \mathrm{i}$ tym samym podsuwa istotne tematy formacyjne dla

${ }^{41}$ DOK 70.

42 DOK 71.

43 S. Eabendowicz, Katecheza dorostych Kościoła posoborowego w świetle dokumentów i literatury katechetycznej,dz. cyt., s. 338-350.

${ }_{44}$ M. Duda, Myślac parafia... Papieża Jana Pawła II wizja parafii. Studium teologiczno-pastoralne, Częstochowa 2006, s. 257.

${ }_{45}$ M. Duda, Myślac parafia..., dz. cyt., s. 258.

46 P. Tomasik, Miejsce katechezy dorosłych $w$ duszpasterstwie polskim, w: Katecheza dorosłych we wspólnocie Kościoła, red. K. Misiaszek, Warszawa 2002, s. 214; F. Woronowski, Zarys teologii pastoralnej, t. 3, Warszawa 1988, s. 23-30.

${ }_{47}$ M. Duda, Soborowa i posoborowa wizja parafii, w: M. Duda, Parafia - kawałek nieba... do moich Parafian i nie tylko... 1996-2003, Częstochowa 2004, s. 191-197.

48 R. Kamiński, Duszpasterstwo w społeczeństwie pluralistycznym, Lublin 1997, s. 66; E. Sztafrowski, Urzeczywistnianie się Kościoła w duszpasterstwie parafialnym, w: Duszpasterstwo w świetle nowego Kodeksu Prawa Kanonicznego, red. J. Syryjczyk, Warszawa 1985, s. 57-58. 
katechezy dorosłych. Wskazówki dotyczące katechezy dorosłych odnoszą się do dorosłych świeckich ${ }^{49}$. Osoby konsekrowane objęte są w inny sposób stałą formacją i opieką duszpasterską.

Dyrektoria katechetyczne wyróżniają trzy grupy dorosłych podzielone ze względu na ich zaangażowanie w wiarę, które powinny być objęte katechezą dorosłych.

Pierwszą grupę stanowią dorośli wierzący, którzy spójnie przeżywają swój wybór wiary i pragną jej pogłębienia. Do nich będzie skierowana katecheza stała. Wśród form katechetycznych można tutaj wyróżnić katechezę podejmowaną przez ruchy, stowarzyszenia i organizacje katolickie, zwłaszcza Akcję Katolicką $a^{50}$; rekolekcje zamknięte $e^{51}$; katechezę w trakcie pieszych i autokarowych pielgrzymek do sanktuariów ${ }^{52}$. Dla tej grupy osób dorosłych wskazane są także kursy katechezy systematycznej, jak $n p$. kursy biblijne ${ }^{53}$. Nie sposób zapomnieć o katechezie w ramach dusz-

49 PDK 98, 101; DOK 174; Międzynarodowa Rada do Spraw Katechezy, Katecheza dorosłych we wspólnocie chrześcijańskiej. Niektóre linie i ukierunkowania [dalej: KDWCh], Watykan 1990, 26, 50. Przekł. pol.: tłum. K. Misiaszek, Kraków 2001. W odniesieniu do katechezy dorosłych warto zwrócić jeszcze uwagę na dokument zatwierdzony w 1970 roku przez Konferencję Episkopatu Polski, a mianowicie Dyrektorium apostolstwa świeckich, w: Komisja Episkopatu Polski ds. Duszpasterstwa Ogólnego, Ewangelizacja w tajemnicy i misji Kościoła. Materiały formacyjne i homiletyczne w roku duszpasterskim 1994/95, Katowice 1994, s. 352-375 oraz adhortację apostolską Jana Pawła II o powołaniu i misji świeckich w Kościele dwadzieścia lat po Soborze Watykańskim II Christifideles laici.

50 PDK 102. O ruchach i stowarzyszeniach wspomina również dokument Międzynarodowej Rady do Spraw Katechezy Katecheza dorosłych we wspólnocie chrześcijańskiej- KDWCh 63. Należy zauważyć, że katecheza prowadzona w ramach ruchów i stowarzyszeń może być ograniczona do określonego charyzmatu danego ruchu czy stowarzyszenia. Nie jest jej celem przekazywanie całokształtu prawd objawienia w sposób usystematyzowany ani też zapoznanie z orędziem biblijnym. Katechetycy zwracają uwagę, że nie należy utożsamiać katechezy dorosłych z różnorodnymi ruchami i stowarzyszeniami (K. Misiaszek, Zagadnienie katechezy dorosłych według dokumentu „Katecheza dorosłych we wspólnocie chrześcijańskiej", w: Katecheza dorosłych we wspólnocie Kościoła, dz.cyt., s. 58-59; S. Łabendowicz, Katecheza dorosłych Kościoła posoborowego w świetle dokumentów i literatury katechetycznej, dz.cyt., s. 356), ponieważ nie wszyscy dorośli do nich należą - PDK 102; KDWCh 63. Jednakże w odniesieniu do formacji biblijnej nie sposób nie docenić wielu ruchów, które wdrażają swoich członków do pogłębionego czytania i rozważania Pisma Świętego (Ruch Światło-Życie, Domowy Kościół, Neokatechumenat i inne).

$\begin{array}{ll}{ }_{51} & \text { PDK } 104 . \\ { }_{52} & \text { PDK } 104 \\ & \text { PDK } 101 .\end{array}$ 
pasterstwa masowego w formie niedzielnej homiliiis; katechezie odnoszącej się do problematyki zawartej w programie duszpasterskim danego roku kościelnego, również w ramach kazań głoszonych z racji nabożeństw pasyjnych na gorzkich żalach i nabożeństw okresowych w maju, czerwcu i październiku. Bibliści od wielu lat proponują wykorzystanie nabożeństw październikowych na biblijne pogłębienie tajemnic różańcowych, zawsze z krótkim komentarzem ${ }^{55}$. Osoby z tej grupy są również słuchaczami kazań eucharystycznych w okresie oktawy Bożego Ciała ${ }^{56}$.

Drugą grupę katechizowanych stanowią dorośli, którzy zostali ochrzczeni, lecz oddalili się od wiary. Ta grupa potrzebuje katechezy ewangelizacyjnej i wtajemniczającej. Dla tej grupy osób wskazane jest uczestnictwo w dorocznych rekolekcjach lub całotygodniowych misjach ${ }^{57}$.

Trzecią grupę stanowią dorośli nieochrzczeni ${ }^{58}$. Dla nich przeznaczone są głównie formy katechezy okazjonalnej, uwzględniającej różne sytuacje i okoliczności, domagające się światła orędzia Bożego ${ }^{59}$ i zachęcające uczestników do wejścia na drogę wiary. Ta grupa potrzebuje na początku działań ewangelizacyjnych. Następnie formacja tych osób odbywa się według wskazań Obrzędów chrześcijańskiego wtajemniczenia dorosłych. Jest to katecheza wtajemniczająca i mistagogiczna.

\section{Grupy dorosłych w parafii podzielone ze względu na szczególne sytuacje}

Dyrektorium ogólne o katechizacji mówi o katechezie w szczególnych sytuacjach, mentalnościach i środowiskach. Wymieniona jest katecheza niepełnosprawnych i nieprzystosowanych ${ }^{60}$, katecheza zepchniętych na

54 PDK 102.

55 J. Kudasiewicz, Proforystyka pastoralna, s. 271-272; J. Kudasiewicz, Pismo św. w naszej parafii, „Kielecki Przegląd Diecezjalny” 40 (1964) nr 4, s 178; S. Łach, Pismo św. w rodzinach katolickich, „Homo Dei” 19 (1950) nr 4-5, s. 677.

\footnotetext{
56 PDK 117.

57 PDK 117.

58 PDK 99; DOK 172.

59 PDK 101.

60 DOK 189.
} 
margines ${ }^{61}$, katecheza dla grup zróżnicowanych ${ }^{62}$ oraz katecheza środowiskowa $^{63}$. Również dokument Międzynarodowej Rady do spraw Katechezy zatytułowany Katecheza dorosłych we wspólnocie chrześcijańskiej wśród odbiorców katechezy dorosłych wyróżnia tych, którzy są pozostawieni na marginesie życia: niepełnosprawni fizycznie i psychicznie, osoby w podeszłym wieku, chorzy i najbardziej zagrożeni życiową marginalizacją (uchodźcy, emigranci, nomadzi, więźniowie) ${ }^{64}$. Te osoby w zależności od swojej kondycji religijnej mogą potrzebować różnych form i rodzajów katechezy.

\section{Inne grupy dorosłych w parafii}

\subsection{Rodzice}

Dyrektorium katechetyczne Kościoła katolickiego w Polsce zwraca uwagę na katechezę dorosłych adresowaną do rodziców w ramach przygotowania ich dzieci do sakramentów świętych: chrztu, Pierwszej Komunii Świętej i sakramentu pokuty, rocznicy I Komunii Świętej oraz sakramentu bierzmowania ${ }^{65}$. Dla tej grupy wskazana jest katecheza wtajemniczająca skoncentrowana na sakramentach, które będą przeżywane w rodzinie ${ }^{66}$. Pogłębienie przeżywania sakramentów wtajemniczenia chrześcijańskiego przez rodziców wpłynie na bezpośrednie przygotowanie się do przyjęcia tych sakramentów przez dzieci. Murawski zwraca uwagę na priorytetowe znaczenie tej formy katechezy i rozciąga ją na katechizację różnych grup dzieci uczęszczających na katechezę, a więc katechizację rodziców mających dzieci w wieku przedszkolnym i następnie uczących się w różnych typach szkół ${ }^{67}$.

61 DOK 190.

62 DOK 191.

63 DOK 192.

64 KDWCh 55.

65 PDK 103.

66 PDK 103.

67 R. Murawski, Kierunki i formy pracy katechetycznej z dorostymi, dz. cyt., s. 74-75. Zob. również: S. Łabendowicz, Katecheza dorosłych Kościoła posoborowego w świetle dokumentów i literatury katechetycznej, dz. cyt., s. 345; J. Majka, Problem katechizacji dorosłych na tle wspótczesnej rzeczy- 
Katecheza adresowana do rodziców może być zachętą do rodzinnego czytania Pisma Świętego. Bibliści sugerują, że lektura rodzinna winna być regularna: codzienna lub cotygodniowa. Lektura codzienna powinna mieć charakter kursoryczny, a lektura cotygodniowa - najlepiej w wigilie niedziel i świąt - charakter liturgiczny, tzn. jako lekturę można wybrać perykopy biblijne przypadające na dane święto według porządku czytańn ${ }^{68}$.

\subsection{Dorośli posługujący w liturgii}

Dokumenty katechetyczne nie wspominają o katechezie dorosłych posługujących w liturgii. Dyrektorium katechetyczne Kościoła katolickiego $w$ Polsce o zespołach liturgicznych mówi tylko w odniesieniu do dzieci i młodzieży, nie odnosząc ich do katechezy dorosłych ${ }^{69}$. Jednakże II Polski Synod Plenarny w odniesieniu do parafii zaleca zespoły liturgiczne, które złożone są z dorosłych, młodzieży i dzieci ${ }^{70}$. Podobnie wypowiada się Dyrektorium duszpasterstwa służby liturgicznej ${ }^{71}$.

Dorośli mogą włączyć się we wspólnotę lektorów, psałterzystów, akolitów, przynoszących dary i zbierających składkę lub śpiewających w chó$\mathrm{rze}^{72}$. Innymi funkcjami liturgicznymi, które mogą podjąć dorośli, są posługi nadzwyczajnych szafarzy Komunii Świętej, animatorów liturgicznych,

wistości religijno-społecznej, w: Powołanie człowieka. W stużbie Ludowi Bożemu, red. B. Bejze, t. 6, Poznań-Warszawa 1983, s. 452-455, 461; E. Majcher, Wspótudział rodziców w katechizacji parafialnej, w: Powołanie człowieka, dz.cyt., s. 448-450.

${ }_{68}$ J. Kudasiewicz, Proforystykapastoralna. Pismo Świętejako księga Ludu Bożego, w: Wstęp ogólny do Pisma Świętego, red. J. Szlaga, Poznań-Warszawa 1986, s. 272-273; R. Kamiński, Biblia w życiu parafii i małych wspólnot religijnych, w: Biblia w nauczaniu chrześcijańskim, red. J. Kudasiewicz, Lublin 1991, s. 165-166.

${ }^{69}$ PDK 110. Nie brak natomiast pozycji o związku katechezy dorosłych z liturgią, zob. W. Nowak, Katecheza dorosłych i liturgia, w: Katecheza dorosłych w teorii i praktyce, s. 137157. W podanym artykule mowa jest o przygotowaniu dorosłych w celebrowaniu misterium Chrystusa w liturgii, bez wskazania możliwości podjęcia w czasie liturgii różnych posług, które mogą spełniać świeccy.

70 II Polski Synod Plenarny (1991-1999). Liturgia Kościoła po Soborze Watykańskim II, Poznań $2001,83$.

${ }^{71}$ Konferencja Episkopatu Polski, Dyrektorium duszpasterstwa służby liturgicznej [dalej: DDSL], Kraków 2009, 3, 54, 100-146.

72 DDSL 105. Mężczyźni mogą być ustanowieni na stałe akolitami lub lektorami. Ich formacja przeprowadzana jest w diecezji - DDSL 109. 
ceremoniarzy, organistów, kantorów i dyrygentów chóru, zakrystianów ${ }^{73}$. Główny ciężar formacji służby liturgicznej spoczywa na parafii ${ }^{74}$. W miarę rozwoju grup liturgicznych tworzy się w parafii liczna wspólnota osób, do której należą dorośli, którzy coraz bardziej wytrwale chcą dążyć do świętości ${ }^{75}$.

W Dyrektorium duszpasterstwa służby liturgicznej zwrócono uwagę, że zaangażowanie dorosłych w służbę liturgiczną rozwija się dwiema drogami: jako kontynuacja posługiwania podejmowanego w dzieciństwie i młodości oraz jako podjęcie posługi w wieku dorosłym ${ }^{76}$. Dla tych ostatnich wskazany jest krótki okres wprowadzający ${ }^{77}$, a następnie trzyletnia formacja wstępna koncentrująca się na tych tematach, które podejmują młodzieżowe zespoły liturgiczne: słowo ${ }^{78}$, sakrament ${ }^{79}$, wspólnota ${ }^{80}$. Pierwszy rok koncentruje się na głębszym wprowadzeniu w słowo Boże. Jednakże uwzględniając trzyletni niedzielny cykl czytań mszalnych (rok A, B i C) oraz dwuletni cykl dni powszednich (Rok I i II), należy liczyć się z potrzebą kilkuletniego okresu wprowadzania dorosłych w teksty biblijne czytane w czasie liturgii, a później z biblijną formacją permanentną.

Dla osób dorosłych posługujących w liturgii wskazana jest katecheza mistagogiczna oraz stała prowadzona permanentnie.

\subsection{Katecheci}

Dyrektoria katechetyczne wśród obowiązków proboszcza odnośnie do katechezy wymieniają m.in. wzbudzanie we wspólnocie chrześcijańskiej zmysłu wspólnej odpowiedzialności za katechezę jako zadania wszystkich ochrzczonych; troszczenie się o odpowiednie zaprogramowanie posłu-

73 DDSL 131-146. Nadzwyczajni szafarze Komunii Świętej, animatorzy liturgiczni, ceremoniarze, organiści również w diecezji otrzymują podstawową formację do wykonywania swojej posługi. Ale w parafii mogą otrzymywać formację stałą.

74 DDSL 164.

75 DDSL 167.

76 DDSL 100.

77 DDSL 104.

78 DDSL 91-92.

79 DDSL 93-94.

80 DDSL 95-96. 
gi katechetycznej w parafii, by była właściwie zorganizowana i pokierowana, a także zadbanie o należyty jej poziom; wzbudzanie powołania do posługi katechetycznej wśród osób świeckich oraz okazywanie uznania tym osobom, które się tej posługi podejmują ${ }^{81}$; a także odbywanie regularnych spotkań ze wszystkimi, którzy wykonują jakąś formę posługi katechetycznej w parafii ${ }^{82}$. Takie spotkania mogą być okazją do podjęcia systematycznej katechezy stałej katechetów.

\section{Treści katechezy biblijnej w parafii}

Przekaz treści biblijnych w parafii może mieć charakter liturgiczny półciągły, kursoryczny (ciągły) oraz tematyczny. Z przekazem treści o charakterze liturgicznym mamy do czynienia najczęściej podczas homilii oraz w czasie spotkań studyjnych grup lektorskich, gdy omawiane są fragmenty przeznaczone do czytania podczas liturgii słowa. Z przekazem treści o charakterze kursorycznym mamy do czynienia wówczas, gdy w jakiejś grupie czytane są i omawiane poszczególne księgi biblijne w sposób kursoryczny. Z przekazem treści o charakterze tematycznym mamy do czynienia wówczas, gdy omawiane jest wybrane zagadnienie występujące w Biblii. Charakter tematyczny zachowany będzie również wtedy, gdy dana grupa zapoznawana jest z wybranymi fragmentami, np. róże różańcowe mogą być zapoznawane z perykopami biblijnymi dotyczącymi tajemnic różańcowych.

Dla osób dorosłych uczestniczących w katechezie ewangelizacyjnej głównymi treściami katechezy biblijnej będzie Osoba Jezusa Chrystusa przedstawiana w ewangeliach. Przekaz treści będzie miał charakter tematyczny.

Dla osób dorosłych uczestniczących w katechezie wtajemniczającej głównymi treściami katechezy biblijnej będą teksty przybliżające rzeczywistość sakramentu chrztu, bierzmowania i Eucharystii oraz historia biblijna na kanwie Starego i Nowego Testamentu. Przekaz treści również będzie miał charakter tematyczny.

81 PDK 140; DOK 225.

82 PDK 141. 
Dla osób dorosłych uczestniczących w katechezie mistagogicznej głównymi tematami katechezy biblijnej będą treści przekazywane podczas liturgii słowa niedzielnych i powszednich mszy świętych. Przekaz treści będzie miał charakter liturgiczny.

Dla osób dorosłych uczestniczących w katechezie stałej głównymi treściami katechezy biblijnej będzie orędzie poszczególnych ksiąg biblijnych czytanych w sposób ciągły. Przekaz treści będzie miał charakter kursoryczny.

\section{Podsumowanie}

Niniejszy artykuł podjął zagadnienie katechezy biblijnej skierowanej do osób dorosłych w świetle obowiązujących dokumentów kościelnych i opracowań. Przedstawiono zagadnienie duszpasterstwa katechetycznego w parafii, etapy katechezy parafialnej, grupy osób dorosłych objętych katechezą oraz treści katechezy biblijnej w parafii. Najwięcej uwagi poświęcono grupom katechetycznym. Wyróżniono w nich osoby podzielone ze względu na zaangażowanie w sprawy wiary, osoby podzielone ze względu na szczególne sytuacje życiowe oraz inne grupy katechetyczne. Zwrócono uwagę, że do wszystkich tych grup osób dorosłych powinna być skierowana odpowiednia katecheza, w tym również katecheza biblijna. Przedstawiono zarys treści katechezy biblijnej przekazywanej podczas katechezy ewangelizacyjnej, wtajemniczającej, mistagogicznej i stałej. Dokładniejsze przedstawienie treści katechezy biblijnej skierowanej do osób dorosłych wymaga oddzielnego opracowania. 


\section{Summary}

\section{Katecheza biblijna w parafii skierowana do różnych grup dorosłych}

W niniejszym artykule w oparciu o dokumenty kościelne i opracowania katechetyczne przedstawiono zagadnienie duszpasterstwa katechetycznego w parafii, etapy katechezy parafialnej, grupy osób dorosłych objętych katechezą oraz treści katechezy biblijnej w parafii.

Najwięcej uwagi poświęcono grupom katechetycznym. Wyróżniono w nich osoby podzielone ze względu na zaangażowanie w sprawy wiary, osoby podzielone ze względu na szczególne sytuacje życiowe oraz inne grupy katechetyczne, czyli rodziców, dorosłych posługujących w liturgii oraz katechetów.

Do wszystkich tych grup osób dorosłych powinna być skierowana odpowiednia katecheza, w tym również katecheza biblijna otwierająca na spotkanie z Chrystusem obecnym w słowie Bożym.

Słowa kluczowe: parafia, katecheza biblijna, katecheza dorosłych

\section{Parish Biblical Catechesis Directed towards Various Groups of Adults}

The present paper describes the problem of parish catechetical ministry, as well as the levels of parish catechesis, groups of adults for which catecheses are intended, and the subject matter of parish biblical catechesis, taking into account the Church documents and catechetical guidelines.

Most of the attention was paid to the catechetical groups. There were distinguished groups of adults classified according to their degree of adherence to the faith, or according to their specific life situations, as well as other catechetical groups i.e. parents, lay liturgical ministers, and catechists.

A proper catechesis should be directed towards each of these groups of adults. This concerns also the biblical catechesis which prepares to meet Christ present in the Word of God.

Keywords: parish, biblical catechesis, adult catechesis

\section{Bibliografia}

Benedykt XVI, Adhortacja Verbum Domini.

Duda M., Myślac parafia... Papieża Jana Pawła II wizja parafii. Studium teologiczno-pastoralne, Częstochowa 2006.

Duda M., Soborowa i posoborowa wizja parafii, w: M. Duda, Parafia - kawałek nieba... do moich Parafian i nie tylko... 1996-2003, Częstochowa 2004, s. 191-197. 


\section{Beata Stypułkowska}

Franciszek, Adhortacja Evangelii gaudium.

http://episkopat.pl/kosciol/kosciol_w_polsce/statystyki/6013.1,Zestawienie_ dominicantes_i_communicantes_2013.html (2016.03.30).

http://www.opoka.org.pl/biblioteka/T/TA/TAP/communicantes2013.html (2016.03.30).

II Polski Synod Plenarny (1991-1999). Liturgia Kościoła po Soborze Watykańskim II, Poznań 2001.

Jan Paweł II, Adhortacja Catechesi tradendae.

Jan Paweł II, Adhortacja Christifideles laici.

Kamiński R., Biblia w życiu parafii i małych wspólnot religijnych, w: Biblia w nauczaniu chrześcijańskim, red. J. Kudasiewicz, Lublin 1991, s. 139-168.

Kamiński R., Duszpasterstwo w społeczeństwie pluralistycznym, Lublin 1997.

Katecheza ewangelizacyjna. Poszukiwania koncepcji, red. P. Mąkosa, Lublin 2010.

Kochel J., Katecheza ewangelizacyjna w nauczaniu pastoralnym Carlo Maria Kard. Martiniego, Opole 1999.

Konferencja Episkopatu Polski, Dyrektorium apostolstwa świeckich, w: Komisja Episkopatu Polski ds. Duszpasterstwa Ogólnego, Ewangelizacja w tajemnicy i misji Kościoła. Materiały formacyjne i homiletyczne w roku duszpasterskim 1994/95, Katowice 1994, s. 352-375.

Konferencja Episkopatu Polski, Dyrektorium duszpasterstwa służby liturgicznej, Kraków 2009.

Konferencja Episkopatu Polski, Dyrektorium katechetyczne Kościoła katolickiego w Polsce, Kraków 2001.

Kongregacja ds. Duchowieństwa, Dyrektorium ogólne o katechizacji, Poznań 1998.

Kudasiewicz J., Pismo św. w naszej parafii, „Kielecki Przegląd Diecezjalny” 40 (1964) nr 4, s. 164-183.

Kudasiewicz J., Proforystyka pastoralna. Pismo Święte jako księga Ludu Bożego, w: Wstęp ogólny do Pisma Świętego, red. J. Szlaga, Poznań-Warszawa 1986, s. 221-275.

Łabendowicz S., Katecheza dorosłych Kościoła posoborowego w świetle dokumentów i literatury katechetycznej, Radom 2007.

Łabendowicz S., Katecheza w służbie ewangelizacji, „Roczniki Teologiczno-Kanoniczne” 36 (1989), z. 6, s. 129-145.

Łach S., Pismo św. w rodzinach katolickich, „Homo Dei” 19 (1950) nr 4-5, s. 670-678.

Majcher E., Wspótudział rodziców w katechizacji parafialnej, w: Powołanie człowieka. W służbie Ludowi Bożemu, red. B. Bejze, t. 6, Poznań-Warszawa 1983, s. 437-451.

Majka J., Problem katechizacji dorosłych na tle współczesnej rzeczywistości religijno-społecznej, w: Powołanie człowieka. W stużbie Ludowi Bożemu, red. B. Bejze, t. 6, PoznańWarszawa 1983, s. 452-464.

Marek Z., Jezus Chrystus w katechezie ewangelizacyjnej, w: Ewangelizować czy katechizować, red. S. Dziekoński, Warszawa 2002, s. 89-96.

Międzynarodowa Rada do Spraw Katechezy, Katecheza dorosłych we wspólnocie chrześcijańskiej. Niektóre linie i ukierunkowania, Watykan 1990. Przekł. pol. K. Misiaszek, Kraków 2001. 
Misiaszek K., Mistagogia w katechezie, w: Mistagogia a duchowość, red. A. Żądło, Katowice 2004, s. 81-90.

Misiaszek K., Zagadnienie katechezy dorosłych według dokumentu „Katecheza dorosłych we wspólnocie chrześcijańskiej”, w: Katecheza dorosłych we wspólnocie Kościoła, red. K. Misiaszek, Warszawa 2002, s. 49-60.

Murawski R., Działania katechetyczne w parafii w świetle Dyrektorium Ogólnego i Polskiego, w: Przestanie dokumentów katechetycznych Kościoła w Polsce, red. S. Dziekoński, Warszawa 2003, s. 55-70.

Murawski R., Ewangelizacyjny charakter katechezy, „Ateneum Kapłańskie” 84 (1992) nr 2, s. 181-193.

Murawski R., Kierunki i formy pracy katechetycznej z dorosłymi w parafii, „Śląskie Studia Teologiczno-Historyczne" 13 (1980), s. 65-80.

Neumann J., Dlaczego katecheza ewangelizacyjna? w: Ewangelizować czy katechizować, red. S. Dziekoński, Warszawa 2002, s. 133-143.

Niparko R., Katecheza dorosłych. Zarys teorii, Poznań 1987.

Nonis P., Ewangelizacja a katecheza, w: Nowa ewangelizacja, red. L. Balter i in., Poznań 1993, s. 96-100 (Kolekcja Communio, 8).

Nowak W., Katecheza dorosłych i liturgia, w: Katecheza dorosłych w teorii i praktyce. Impulsy - wyzwania - perspektywy, red. C. Rogowski, Lublin-Olsztyn 2001, s. 137-157.

Obrzędy chrześcijańskiego wtajemniczenia dorosłych. Dostosowane do zwyczajów diecezji polskich, Katowice 1988.

Offmański A., Katecheza jako ewangelizacja. Ewangelizacyjna funkcja katechezy, „Horyzonty Wiary” 7 (1996), nr 3, s. 9-20.

Offmański A., Model katechezy ewangelizacyjnejw dokumentach Kościoła, w: Ewangelizować czy katechizować, red. S. Dziekoński, Warszawa 2002, s. 53-72.

Sławiński H., Między ciagłościa a zmiana. Teoria homilii w Stanach Zjednoczonych po II Soborze Watykańskim, Kraków 2008.

Stypułkowska B., Biblijna formacja katechetów, Częstochowa 2015.

Stypułkowska B., Katecheza biblijna w parafii skierowana do osób dorosłych, „Analecta Cracoviensia" 46 (2014), s. 155-170.

Sztafrowski E., Urzeczywistnianie się Kościoła w duszpasterstwie parafialnym, w: Duszpasterstwo w świetle nowego Kodeksu Prawa Kanonicznego, red. J. Syryjczyk, Warszawa 1985, s. 57-68.

Tomasik P., Ewangelizacja - katecheza - nauczanie religii w szkole. Wyjaśnienie podstawowych terminów, w: Ewangelizować czy katechizować, red. S. Dziekoński, Warszawa 2002, s. 23-51.

Tomasik P., Katecheza w misji ewangelizacyjnej Kościoła, „Katecheta” 42 (1998) nr 6-7, s. 9-18.

Tomasik P., Miejsce katechezy dorostych $w$ duszpasterstwie polskim, w: Katecheza dorosłych we wspólnocie Kościoła, red. K. Misiaszek, Warszawa 2002, s. 199-229.

Woronowski F., Zarys teologii pastoralnej, t. 3, Warszawa 1988. 